\title{
Interleukin-1 as a Key Factor in the Development of Inflammatory Diseases
}

\author{
Shirin Farivar ${ }^{1,2}$; Mahdieh Hassani ${ }^{1}$; Reza Shiari ${ }^{3,4, *}$ \\ ${ }_{2}^{1}$ Department of Genetics, Faculty of Biological Sciences, Shahid Beheshti University of Medical Sciences, Tehran, IR Iran \\ ${ }^{2}$ Laser and Plasma Research Institute, Shahid Beheshti University of Medical Sciences, Tehran, IR Iran \\ 3 Department of Pediatric Rheumatology, Shahid Beheshti University of Medical Sciences, Tehran, IR Iran \\ ${ }^{4}$ Pediatric Infections Research Center, Mofid Children's Hospital, Shahid Beheshti University of Medical Sciences, Tehran, IR Iran \\ ${ }^{*}$ Corresponding author: Reza Shiari, Department of Pediatric Rheumatology, Shahid Beheshti University of Medical Sciences, Tehran, IR Iran. Tel/Fax: +98-2122227033, E-mail: \\ shiareza@yahoo.com \\ Received: February 11, 2014; Accepted: March 15, 2014
}

\begin{abstract}
Context: High levels of interleukin-1 have been implicated in uncontrolled inflammation and fever in inflammatory diseases, including; familial Mediterranean fever, cryopyrin associated periodic syndrome, Behcet's disease and systemic onset juvenile idiopathic arthritis. The underlying specific genetic causes for these diseases have not yet been elucidated due to inferring factors, such as high levels of interleukin-1 beta (IL-1 1 ) in the blood and etiology, as well as the disease manifestations.

Conclusions: This review discusses the role of interleukin-1 beta and interleukin-18 production pathways in the development of systemic onset juvenile idiopathic arthritis and familial Mediterranean fever disease.
\end{abstract}

Keywords: Autoimmune Diseases; Interleukin 1 Receptor Antagonist Protein; Cytokines

\section{Context}

Cytokines and chemokines are a group of small proteins that are critical to the maturation, differentiation, and activation of cells. They are also involved in cell mobility and consequently affect the integrity of the extracellular matrix. The interleukin-1 (IL-1) super family is one of the most important families of cytokines. Other members of the IL-1 super family are; IL-1 $\alpha$, IL-1 $1 \beta$, IL-1 receptor antagonist (IL-1RA), IL-18 (1), and IL-33 (2). The IL-1 family members are shown in Table 1. High levels of IL-1 $\beta$ have been implicated in uncontrolled inflammation and fever in inflammatory diseases, including; familial Mediterranean fever (FMF), cryopyrin associated periodic syndrome (CAPS), Behcet's disease, and systemic onset juvenile idiopathic arthritis (SoJIA) (3). The underlying specific genetic causes for these diseases have not yet been elucidated due to inferring factors such as; high levels of IL-1 $\beta$ in the blood, and the etiology as well as manifestations of the diseases. This review discusses the implications of IL-1 $\beta$ and IL-18 production pathways in the development of SoJIA and FMF diseases.

\section{Evidence Acquisition}

\subsection{Process of IL-1 $\beta$ Production}

The innate immunity system has two kinds of receptors

\begin{tabular}{|c|c|c|c|}
\hline $\begin{array}{l}\text { Family } \\
\text { Name }\end{array}$ & $\begin{array}{l}\text { Old } \\
\text { Name }\end{array}$ & Property & $\begin{array}{l}\text { Chromosomal } \\
\text { Location }\end{array}$ \\
\hline IL-1F1 & IL-1 $\alpha$ & proinflammatory & 2p14 \\
\hline IL-1F2 & IL-1 $\beta$ & proinflammatory & $2 \mathrm{q} 14$ \\
\hline IL-1F3 & IL-1Ra & $\begin{array}{l}\text { antagonist for } \\
\text { IL-1 } \alpha, \text { IL-1 } \beta\end{array}$ & $2 \mathrm{q} 14.2$ \\
\hline IL-1F4 & IL-18 & proinflammatory & $11 \mathrm{q} 22.2-\mathrm{q} 22.3$ \\
\hline IL-1F5 & IL-36Ra & 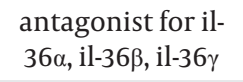 & $2 q 14$ \\
\hline IL-1F6 & IL-36 $\alpha$ & proinflammatory & 2q12-q14.1 \\
\hline IL-1F7 & IL-37 & anti-inflammatory & 2q12-q14.1 \\
\hline IL-1F8 & IL-36 $\beta$ & proinflammatory & $2 q 14$ \\
\hline IL-1F9 & IL-36 $\gamma$ & proinflammatory & $2 q 12-q 21$ \\
\hline IL-1F10 & IL-38 & unknown & $2 \mathrm{q} 13$ \\
\hline IL-1F11 & IL-33 & $\begin{array}{l}\text { th2 responses, } \\
\text { proinflammatory }\end{array}$ & 9p24.1 \\
\hline
\end{tabular}

for the recognition and response to extracellular and intracellular hazardous molecules. Toll-like receptor molecules (TLR) sense extracellular microbial elements, such as peptidoglycans in the cell-wall. Recognition of

Implication for health policy/practice/research/medical education:

High levels of interleukin-1 have been implicated in uncontrolled inflammation and fever in inflammatory diseases.

Copyright @ C 2014, Pediatric Infections Research Center. This is an open-access article distributed under the terms of the Creative Commons Attribution-NonCommercial 4.0 International License (http://creativecommons.org/licenses/by-nc/4.0/) which permits copy and redistribute the material just in noncommercial usages, provided the original work is properly cited. 
the ligands by TLRs leads to the expression of a number of immune and inflammatory proteins. The second receptor type is Nod-like receptors (NLRs), NLRs respond to various endogenous cellular molecules. They also recognize pathogens that pass through the cell barrier and enter into the cytoplasmic space. NLRs are cytoplasmic analogs of TLRs. Endogenous substrates for NLRs are comprised of toxins, defective nucleic acids, and normal cell debris. NLRs exhibit three domains including an N-terminal effecter domain (4), an intermediary nucleotide-binding domain; and a C-terminal leucine rich repeat (LRR) domain. LRR domains are short repeat motifs consisting of 22-28 residues of leucine that are found in a variety of cytoplasmic, membrane, and extracellular proteins, such as ribonuclease inhibitors and Toll-like receptors. NLR family genes are classified based on their N-terminal effector domain. Nod-like receptors (NALPs) are members of the NLR subfamily that have a pyrin domain (PYD) in the $\mathrm{N}$-terminal of the molecules. Interactions between TLRs and NALPs lead to the production of pro-IL-1 $\beta$ and other inflammatory cytokines, including IL-18 and IL33 (5-7). NALP3 has received the most attention, and it has been demonstrated that NALP3 is involved in the recognition of numerous exogenous and host molecules (8). The NALP3 inflammasome mediates activation of inflammatory caspase-1. The different components of the NALP3 inflammasome are; NALP3 itself, CARDINAL, ASC, and caspase-1 (9). In turn, caspase-1 cleaves pro-IL-1 $\beta$ to IL-1 $1 \beta$, thus leading to the activation of IL-18 and IL-33. This vicious cycle leads to the maturation of some of the interleukin-1 family members, in particular IL-1 1 (10, 11). Moreover, TLR ligands, such as lipopolysaccharides, induce activation of nuclear factor $\mathrm{\kappa B}$, thereby triggering gene expression and synthesis of pro-IL-1 $\beta$ (8).

\subsection{IL-1 $\beta$ Regulation and Function}

IL-1 $\beta$, which is a pyrogenic cytokine, is produced by monocytes, macrophages, fibroblasts, and dendritic cells. IL-1 $\beta$ is normally produced in infection, injury, or problematic immunologic situations (9). At basal concentrations, it causes; fever, hypotension, and the production of other proinflammatory cytokines, such as IL-6. IL-1 $\beta$ also activates IL-1 receptors on endothelial cells and that may cause the production of IL- 6 and a cutaneous rash (12). In addition, IL-6 stimulates hepatocytes and induces the production of several acute-phase proteins, including C-reactive proteins and serum amyloid A (13). IL-1 receptors in the brain also activate the thermoregulatory center of the hypothalamus and lead to fever.

The synthesis and release of IL-1 $\beta$ is tightly regulated. The immune system uses several mechanisms to regulate excessive production of IL-1 $\beta$, from transcription to post-translational modification (14). Several proteins are believed to regulate IL-1 $\beta$ production by interfering with the recruitment of caspase-1 or by directly disrupting caspase-1 activity. Some of these proteins are CARD-only proteins (COP), Iceberg, the caspase-1 inhibitor proteinase inhibitor 9 (PI-9), and the most important one here, pyrin (15-17).

\subsection{IL-18 and Inflammation}

IL-18 is one component of the IL-1 superfamily, thus it shares the same receptor with IL-1. It is produced by macrophages, dendritic cells and epithelial cells all over the body. The IL-18 receptor has two chains, including IL-18R_ $\alpha$ and IL-18R_ $\beta$. The IL-18 receptor binding site to the $\alpha$ chain of the receptor is similar to the IL-1 receptor type I $(18,19)$. The intracellular chain of the IL-18 receptor contains a Toll domain which phylogenetically link IL-18 to the Toll-like receptors. As mentioned before, TLRs are inducers of the NF-kB pathway which is responsible for pro IL-1 production. A natural IL-18 binding protein (IL-18BP) is a molecule that effectively neutralizes IL-18 activity. IL$18 \mathrm{BP}$ is a constitutively secreted, high-affinity and specific inhibitor of IL-18, in addition, alternate mRNA splicing of IL-18BP results in four isoforms $(20,21)$. The ' $\mathrm{A}$ ' isoform is present in the serum of healthy humans at an excess 20-fold molar compared with IL-18 (22). Highly elevated levels of IL-18 have been reported in inflammatory disease (23) for instance serum levels of IL-18 were significantly higher in systemic JIA patients (24).

\subsection{Pyrin as a Mediator of IL-1 $\beta$ Regulation}

MEFV is the gene coding pyrin. Mutations in this gene cause familial Mediterranean fever, a recessively inherited systemic autoinflammatory disorder characterized by short recurrent bouts of fever and serosal, synovial, or cutaneous inflammation, and sometimes this leads to AA amyloidosis (25). Pyrin (or marenostrin), is a 781aa protein expressed in neutrophils, eosinophils, monocytes, dendritic cells, and synovial fibroblasts (26). Pyrin contains a pyrin domain (PYD) at the N-terminus, which is a member of the death effector-fold domains $(10,27$, 28), two B-boxes and a coiled-coil domain (BBCC) in the middle, as well as a SPRY domain in the C-terminus (also called a B30.2 domain). Pyrin interacts with ASC (29) through homotypic interaction of their N-terminal PYD domains (29). The C-terminal SPRY domain of pyrin binds to the catalytic domains of caspase- 1 and inhibits enzyme activity $(30,31)$. Both the BBCC and the SPRY domain of pyrin interact with proIL-1 $\beta$, although the interaction with the SPRY domain was clearly stronger. Based on researcher findings, pyrin interaction with pro IL-1 $\beta$ depends on the prodomain of pro IL-1 $\beta$, because after maturation of IL-1 $\beta$, this interaction cannot be detected. The inhibitory effects of pyrin on the IL-1 $\beta$ production pathway have been reported in caspase-1 self-activation, and an inhibitory effect of the SPRY on ASC dependent activation of caspase- 1 and IL-1 $1 \beta$ processing (Figure 1). Increased processing and secretion of IL-1 $\beta$ was observed 
Farivar S et al.

in cells in which pyrin was absent. It is proposed that the FMF mutations may affect binding of an unidentified inhibitory interaction partner, or affect the stability or localization of pyrin, and in this way it leads to a higher level of secreted IL-1 $\beta$ and intensified inflammatory responses, as observed in FMF patients. Pyrin ap- pears to play an effective role in the regulation of the systemic inflammatory response, and the correlation of high levels of MEFV expression with adverse outcomes in critically ill children with multiple organ dysfunction syndrome confirms this association (32).

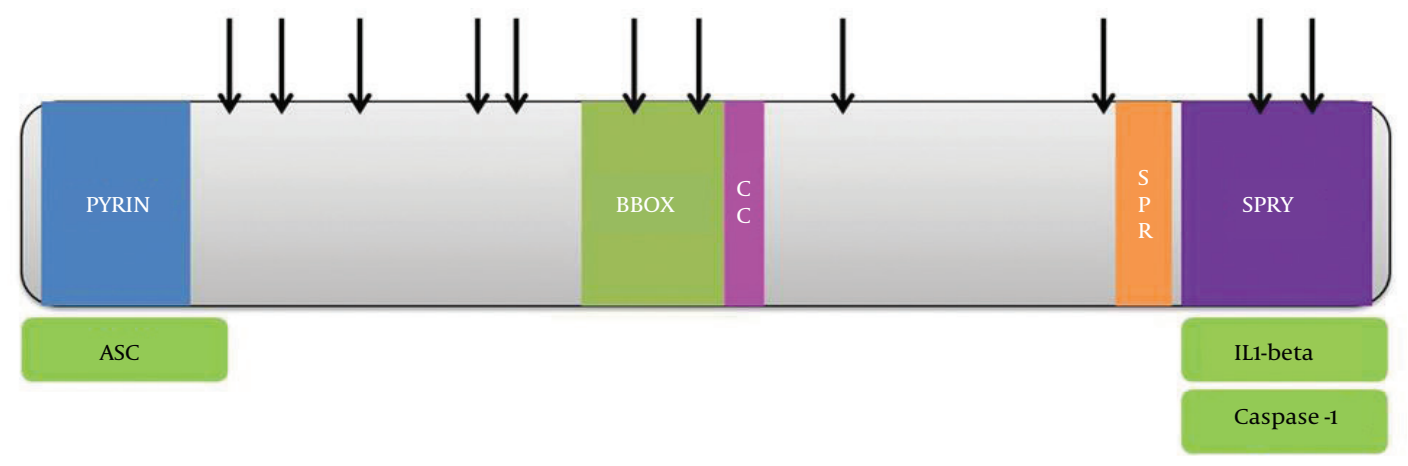

Figure 1. Pyrin Domain Mutations and Interaction With Inflammosome Component Sites

\subsection{Systemic Juvenile Idiopathic Arthritis and IL-1}

In 1897, George Frederic Still summarized his observations on 12 children with systemic onset of juvenile idiopathic arthritis (SoJIA) (33). Systemic juvenile idiopathic arthritis is one of the subtypes of juvenile idiopathic arthritis (JIA). While HLA associations are significant genetic factors in most arthritis subtypes and our previous research prove this relationship, there are few or no associations with SoJIA (34-37). Cases of SoJIA in adolescents are rare and adult onset is reported in only a few cases. In Europe, the incidence of JIA is about 10:100 000/y of which SoJIA represents $6-20 \%(38,39)$. The International League of Associations for Rheumatology classified SoJIA as an arthritis in children starting before 16 years-of-age with symptoms such as; a daily quotidian fever of $39^{\circ} \mathrm{C}$ (or more), persisting for more than two weeks, and at least one of the following clinical symptoms: an evanescent rash, lymphadenopathy, hepatosplenomegaly or serositis $(40,41)$. The outstanding clinical feature that distinguishes SoJIA from other subtypes of JIA is a fever up to more than $39^{\circ} \mathrm{C}$. The second important clinical sign in SoJIA is a cutaneous rash. The serum of SoJIA patients induces the transcription of genes in the innate immune system, including IL-1, in peripheral blood mononuclear cells (PBMCs). In addition, activated monocytes from patients with SoJIA secrete significantly higher amounts of IL-1 $\beta$ in comparison with the monocytes of healthy controls (42). IL-18 also shows very high serum concentrations, with high specificity for SoJIA, compared with other forms of JIA $(43,44)$. IL-1 acts on the bone marrow and stimulates granulopoiesis resulting in neutrophilia of the peripheral blood. IL-1 receptors in the brain activate the thermoregulation of the hypothalamus and lead to fever. IL-1 $\beta$ also activates IL-1 receptors in endothelial cells that may cause a cutaneous rash in SoJIA and result in the production of IL- 6 (45). IL- 6 on the other hand stimulates hepatocytes and induces the production of several acute-phase proteins, like C-reactive protein and serum amyloid A. Serum levels of IL-6 are markedly elevated in patients with SoJIA and this is correlated with systemic features of the disease (13), therefore, IL-6 concentrations in serum are a reflection of IL-1 activity in vivo.

The uncontrolled activation of inflammasomes, and cleavage of pro-IL-1 by caspase-1, have been shown to be important molecular mechanisms in different inherited autoinflammatory syndromes, resulting in spontaneous fever attacks $(46,47)$. Thus, the pathogenesis of SoJIA shows more similarities with auto-inflammatory diseases than with classical antigen-driven auto-immune diseases. No mutations that affect IL-1 $\beta$ regulation have so far been identified in SoJIA patients. However, speculation remains that susceptibility to SoJIA might also involve mutations in particular inflammasome components. Dysregulation of IL-1 $\beta$ production, IL-1Ra proteins, IL-1 type II decoy receptor proteins (48), or the soluble IL$1 \mathrm{R}$ accessory protein (IRAP) (49), might contribute to increased activity of IL-1 $\beta$ in SoJIA. The responsibility of IL-1 $\beta$, and other cytokines for the pathogenesis of SoJIA, can be useful for using cytokine measurement of serum as a diagnostic instrument which can be more effective and low cost than measurements of CRP and ESR. Another benefit is in treatment. Anakinra, a recombinant IL-1 receptor antagonist (IL-1RA), is a new targeted drug which neutralizes the adverse effects of IL-1 superfamily members, such as IL-1 $1 \beta$ and IL-18, by blocking their receptors $(50,51)$.

\section{Conclusions}

Mutations in the MEFV gene, that are responsible for 
FMF disease, have been seen in SoJIA patients and our recent study shows mutations in this gene in Iranian patients (results not published). Pyrin is one of the IL-1 pathway regulators, and increased processing and secretion of IL-1 $\beta$ was observed in cells in which pyrin was absent. We speculate that it could be a major factor involved in the pathogenesis of SoJIA and suggest checking the effect of this mutation in MEFV gene sequence and expression of pyrin on IL-1 $\beta$ production in SoJIA patients. This proven relationship in the pathogenesis of SoJIA and FMF can be useful for making more effective and low cost diagnoses and it could also be a way to develop new molecular and efficient treatments for these diseases.

\section{Acknowledgements}

We would like to express our special appreciation and thanks to the Editorials of Archives of Pediatrics Infectious Diseases.

\section{Authors' Contribution}

Study conception and design: Reza Shiari and Shirin Farivar; analysis and interpretation of data: Shirin Farivar; drafting of manuscript: Mahdieh Hassani; critical revision: Reza Shiari.

\section{Financial Disclosure}

There was no financial disclosure.

\section{Funding/Support}

No funding or support.

\section{References}

1. Chen HF, Shew JY, Ho HN, Hsu WL, Yang YS. Expression of leukemia inhibitory factor and its receptor in preimplantation embryos. Fertil Steril.1999;72(4):713-9.

2. David F, Farley J, Huang H, Lavoie JP, Laverty S. Cytokine and chemokine gene expression of IL-1beta stimulated equine articular chondrocytes. Vet Surg. 2007;36(3):221-7.

3. Church LD, Cook GP, McDermott MF. Primer: inflammasomes and interleukin 1beta in inflammatory disorders. Nat Clin Pract Rheumatol. 2008;4(1):34-42.

4. Fritz JH, Girardin SE. How Toll-like receptors and Nod-like receptors contribute to innate immunity in mammals. JEndotoxin Res. 2005;11(6):390-4.

5. Carriere V, Roussel L, Ortega N, Lacorre DA, Americh L, Aguilar L, et al. IL-33, the IL-1-like cytokine ligand for ST2 receptor, is a chromatin-associated nuclear factor in vivo. Proc Natl Acad Sci U S A 2007;104(1):282-7.

6. Okamura H, Tsutsui H, Kashiwamura S, Yoshimoto T, Nakanishi K. Interleukin-18: a novel cytokine that augments both innate and acquired immunity. Adv Immunol. 1998;70:281-312.

7. Schmitz J, Owyang A, Oldham E, Song Y, Murphy E, McClanahan TK, et al. IL-33, an interleukin-1-like cytokine that signals via the IL-1 receptor-related protein ST2 and induces T helper type 2-associated cytokines. Immunity. 2005;23(5):479-90.

8. Agostini L, Martinon F, Burns K, McDermott MF, Hawkins PN, Tschopp J. NALP3 forms an IL-1beta-processing inflammasome with increased activity in Muckle-Wells autoinflammatory disorder. Immunity. 2004;20(3):319-25.
9. Dinarello CA. Interleukin-1 beta, interleukin-18, and the interleukin-1 beta converting enzyme. Ann NY Acad Sci. 1998;856:1-11.

10. Martinon F, Hofmann K, Tschopp J. The pyrin domain: a possible member of the death domain-fold family implicated in apoptosis and inflammation. Curr Biol. 2001;11(4):R118-20.

11. Martinon F, Tschopp J. Inflammatory caspases and inflammasomes: master switches of inflammation. Cell Death Differ 2007;14(1):10-22.

12. Mariathasan S, Monack DM. Inflammasome adaptors and sen sors: intracellular regulators of infection and inflammation. Nat Rev Immunol. 2007;7(1):31-40.

13. de Benedetti F, Massa M, Robbioni P, Ravelli A, Burgio GR, Martin A. Correlation of serum interleukin-6 levels with joint involvement and thrombocytosis in systemic juvenile rheumatoid arthritis. Arthritis Rheum. 1991;34(9):1158-63.

14. Dinarello CA. Mutations in cryopyrin: bypassing roadblocks in the caspase 1 inflammasome for interleukin-1beta secretion and disease activity. Arthritis Rheum. 2007;56(9):2817-22.

15. Annand RR, Dahlen JR, Sprecher CA, De Dreu P, Foster DC Mankovich JA, et al. Caspase-1 (interleukin-1beta-converting enzyme) is inhibited by the human serpin analogue proteinase inhibitor 9. Biochem J.1999;342 Pt 3:655-65.

16. Humke EW, Shriver SK, Starovasnik MA, Fairbrother WJ, Dixit VM. ICEBERG: A Novel Inhibitor of Interleukin-1 $\beta$ Generation. Cell. 2000;103(1):99-111.

17. Lee SH, Stehlik C, Reed JC. Cop, a caspase recruitment domaincontaining protein and inhibitor of caspase-1 activation processing. Jiol Chem. 2001;276(37):34495-500.

18. Azam T, Novick D, Bufler P, Yoon DY, Rubinstein M, Dinarello CA et al. Identification of a critical Ig-like domain in IL-18 receptor alpha and characterization of a functional IL-18 receptor complex. J Immunol. 2003;171(12):6574-80.

19. Kato Z, Jee J, Shikano H, Mishima M, Ohki I, Ohnishi H, et al. The structure and binding mode of interleukin-18. Nat Struct Biol. 2003;10(11):966-71.

20. Kim SH, Eisenstein M, Reznikov L, Fantuzzi G, Novick D, Rubinstein $\mathrm{M}$, et al. Structural requirements of six naturally occurring is oforms of the IL-18 binding protein to inhibit IL-18. Proc Nat Acad Sci U S A. 2000;97(3):1190-5.

21. Novick D, Kim SH, Fantuzzi G, Reznikov LL, Dinarello CA, Rubinstein M. Interleukin-18 binding protein: a novel modulator of the Th1 cytokine response. Immunity. 1999;10(1):127-36.

22. Novick D, Schwartsburd B, Pinkus R, Suissa D, Belzer I, Sthoeger Z et al. A novel IL-18BP ELISA shows elevated serum IL-18BP in sepsis and extensive decrease of free IL-18. Cytokine. 2001;14(6):334-42.

23. Gracie JA, Forsey RJ, Chan WL, Gilmour A, Leung BP, Greer MR, et al. A proinflammatory role for IL-18 in rheumatoid arthritis. J Clin Invest.1999;104(10):1393-401.

24. Maeno N, Takei S, Nomura Y, Imanaka H, Hokonohara M, Miyata K. Highly elevated serum levels of interleukin-18 in systemic juvenile idiopathic arthritis but not in other juvenile idiopathic arthritis subtypes or in Kawasaki disease: comment on the article by Kawashima et al. Arthritis Rheum. 2002;46(9):2539-41.

25. Farivar S, Shiari R, Hadi E. Molecular analysis of MEFV gene in Iranian children with Familial Mediterranean fever. Indian J Rheumatology. 2010;5(2):66-8

26. Diaz A, Hu C, Kastner DL, Schaner P, Reginato AM, Richards N, et al. Lipopolysaccharide-induced expression of multiple alternatively spliced MEFV transcripts in human synovial fibroblasts: a prominent splice isoform lacks the C-terminal domain that is highly mutated in familial Mediterranean fever. Arthritis Rheum. 2004;50(11):3679-89.

27. Fairbrother WJ, Gordon NC, Humke EW, O'Rourke KM, Starovasnik MA, Yin JP, et al. The PYRIN domain: a member of the death domain-fold superfamily. Protein Sci. 2001;10(9):1911-8.

28. Kohl A, Grutter MG. Fire and death: the pyrin domain joins the death-domain superfamily. C R Biol. 2004;327(12):1077-86.

29. Masumoto J, Taniguchi S, Ayukawa K, Sarvotham H, Kishino T, Niikawa N, et al. ASC, a novel 22-kDa protein, aggregates during apoptosis of human promyelocytic leukemia HL-60 cells. J Biol Chem.1999;274(48):33835-8. 
30. Chae JJ, Wood G, Masters SL, Richard K, Park G, Smith BJ, et al. The B30.2 domain of pyrin, the familial Mediterranean fever protein, interacts directly with caspase-1 to modulate IL-1beta production. Proc Natl Acad Sci U S A. 2006;103(26):9982-7.

31. Papin S, Cuenin S, Agostini L, Martinon F, Werner S, Beer HD, et al. The SPRY domain of Pyrin, mutated in familial Mediterranean fever patients, interacts with inflammasome components and inhibits proIL-1beta processing. Cell Death Differ. 2007;14(8):145766.

32. Hall MW, Gavrilin MA, Knatz NL, Duncan MD, Fernandez SA, Wewers MD. Monocyte mRNA phenotype and adverse outcomes from pediatric multiple organ dysfunction syndrome. Pediatr Res. 2007;62(5):597-603.

33. Still GF. On a Form of Chronic Joint Disease in Children. Med Chir Trans. 1897;80:47-60 9.

34. Farivar S, Shiari R, Hadi E. Genetic susceptibility to juvenile idiopathic arthritis in Iranian children. Arch Med Res. 2011;42(4):301-

35. Glass DN, Giannini EH. Juvenile rheumatoid arthritis as a complex genetic trait. Arthritis Rheum. 1999;42(11):2261-8.

36. Shiari R, Farivar S, Dehghan Tezerjani M. Molecular analysis of HLA-DRB1 alleles in Iranian children with juvenile systemic lupus erythematosus. Pediatr Res. 2013;11(Suppl 2):296.

37. Thomson W, Barrett JH, Donn R, Pepper L, Kennedy LJ, Ollier WE, et al. Juvenile idiopathic arthritis classified by the ILAR criteria: HLA associations in UK patients. Rheumatology (Oxford). 2002;41(10):1183-9.

38. Woo P. Systemic juvenile idiopathic arthritis: diagnosis, management, and outcome. Nat Clin Pract Rheumatol. 2006;2(1):28-34.

39. Woo P, Wedderburn LR. Juvenile chronic arthritis. Lancet. 1998;351(9107):969-73.

40. Petty RE, Southwood TR, Baum J, Bhettay E, Glass DN, Manners P, et al. Revision of the proposed classification criteria for juvenile idiopathic arthritis: Durban, 1997. J Rheumatol.1998;25(10):1991-4.

41. Petty RE, Southwood TR, Manners P, Baum J, Glass DN, Goldenberg J, et al. International League of Associations for Rheumatol- ogy classification of juvenile idiopathic arthritis: second revision, Edmonton, 2001. J Rheumatol. 2004;31(2):390-2.

42. Pascual V, Allantaz F, Arce E, Punaro M, Banchereau J. Role of interleukin-1 (IL-1) in the pathogenesis of systemic onset juvenile idiopathic arthritis and clinical response to IL-1 blockade. J Exp Med. 2005;201(9):1479-86.

43. De Jager W, Hoppenreijs EP, Wulffraat NM, Wedderburn LR, Kuis W, Prakken BJ. Blood and synovial fluid cytokine signatures in patients with juvenile idiopathic arthritis: a cross-sectional study. Ann Rheum Dis. 2007;66(5):589-98.

44. Kawashima M, Yamamura M, Taniai M, Yamauchi H, Tanimoto T, Kurimoto M, et al. Levels of interleukin-18 and its binding inhibitors in the blood circulation of patients with adult-onset Still's disease. Arthritis Rheum. 2001;44(3):550-60.

45. Dinarello CA. Blocking IL-1 in systemic inflammation. J Exp Med. 2005;201(9):1355-9.

46. Hoffman HM, Mueller JL, Broide DH, Wanderer AA, Kolodner RD. Mutation of a new gene encoding a putative pyrin-like protein causes familial cold autoinflammatory syndrome and MuckleWells syndrome. Nat Genet. 2001;29(3):301-5.

47. Tschopp J, Martinon F, Burns K. NALPs: a novel protein family involved in inflammation. Nat Rev Mol Cell Biol. 2003;4(2):95-104.

48. Colotta F, Dower SK, Sims JE, Mantovani A. The type II 'decoy' receptor: a novel regulatory pathway for interleukin 1. Immunol Today. 1994;15(12):562-6.

49. Smith DE, Hanna R, Della F, Moore H, Chen H, Farese AM, et al. The soluble form of IL-1 receptor accessory protein enhances the ability of soluble type II IL-1 receptor to inhibit IL-1 action. Immunity. 2003;18(1):87-96.

50. De Jager W, Vastert SJ, Noordman BJ, Holzinger D, Kuis W, Prakken BJ, et al. Akinra restores the defective IL-18 NK cell axis in steroid naïve systemic onset JIA patients. Pediatr Rheumatol. 2011;9(Suppl 1):O33.

51. Hedrich CM, Bruck N, Fiebig B, Gahr M. Anakinra: a safe and effective first-line treatment in systemic onset juvenile idiopathic arthritis (SoJIA). Rheumatol Int. 2012;32(11):3525-30. 